\title{
"The Price of Everything and the Value of Nothing!?" - What Cultural Capitalism Is and What It Cannot Be Accused of Being
}

\author{
Andreas STAMATE-ȘTEFAN \\ Bucharest University of Economic Studies, Bucharest, Romania \\ andreas.stamate@rei.ase.ro \\ Matei-Alexandru APĂVĂLOAEI \\ Bucharest University of Economic Studies, Bucharest, Romania \\ matei.apavaloaei@rei.ase.ro \\ Vlad I. ROȘCA \\ Bucharest University of Economic Studies, Bucharest, Romania \\ vlad.rosca@fabiz.ase.ro \\ Mihaela IACOB \\ Bucharest University of Economic Studies, Bucharest, Romania \\ mihaela.iacob@fin.ase.ro \\ Octavian-Dragomir JORA \\ Bucharest University of Economic Studies, Bucharest, Romania \\ octavian.jora@rei.ase.ro
}

\begin{abstract}
The present paper is a defense of the free-market economy/capitalism as a proper institutional setting for both producing and preserving cultural goods. We argue that culture is best served by a framework in which economic agents can evaluate their cultural consumption and production in a market order based on private property rights and monetary prices. In this vein, we first put, in contrast, two important lines of thought on the subject of value and capital in cultural matters. On the one hand, the mainstream approach upholds both that "cultural value" is intrinsic (and measurable) and that a fourth type of capital (namely "cultural capital") can be introduced in the capital theory. On the other hand, by using a qualitative research methodology, based on deductive reasoning and historical analysis, we contrast the mainstream/neoclassic view with the praxeological approach of the Austrian School of economics. We conclude that neither "cultural value" is an objective fact, nor that the very concept of "cultural capital" can be integrated coherently in the economic theory. Yet, we claim that private management of cultural goods is superior to their public administration, due to (1) a genuine interest of private owners to rationally exploit cultural goods according to the subjective preferences of cultural consumers, (2) the inbuilt sustainability of the free-market economy as concerns the efficient exploitation of the cultural goods.
\end{abstract}

Keywords: cultural value, cultural capital, free-market capitalism, state interventionism, private property, monetary prices, public patrimony, public regulations.

\section{Introduction}

The assertion that the free market (or capitalism) represents the friendliest social arrangement for culture and art is not a very fashionable one. However, it is capitalism that makes artistic success 
stem from the ability of gifted people to inspire, amuse, or educate those who come in contact with their work and/or in its possession. Art cannot be created by armed force or political privileges, simply because human thoughts and emotions can be neither enforced on others nor expropriated from them. Their expression can only be inhibited and delayed by suppressing their means of expression. Art is at home in markets for, through its liberal nature, it cannot mobilize support other than by convincing either "selfish" or "rapacious" art owners or traders of masterpieces of their worth. The market economy encourages cultural, artistic production in obvious ways. A general increase of wealth facilitates the expansion of art consumption, which translates into artists' possibility to follow their vocation and, at the same time, be remunerated for this. More than ever, in contemporary times, artistic creation has become professionalized. Also, mankind has gotten more and more relieved from the burden of physical labor through technological breakthroughs, human intelligence, and talent becoming available to pursue a wide range of spiritual avenues.

In what follows, we avoided making any judgment about the meaning of beauty: we leave the aesthete his due, and we claim for the economist what is his. The market does not select beauties; it has no mechanism for such a task. However, it allows for their discovery. Moreover, once what is aesthetically pleasing is discovered, the market allows for its multiplication. All this takes place within a constellation of competing needs, where beauty is just one of them, felt with different (utility) intensities among people. All needs are under the aegis of scarcity (even the means of expressing oneself are limited), negotiated in a rival framework where resources follow the law of price, not that of force. A world where "beauty" is imposed by force ends up as an ugly world. Surely, two objections can be raised concerning the "dialectical contradictions" of the art market. First, art is supposed to be born in a cathartic manner, while its monetization devalues it. Second, since the economic criteria are counter-aesthetic, amoral, and self-destructive, the art market is equally predisposed towards rewarding the grotesque, hideous, infectious. We advance only two ideas on these considerations: human life is a sum of shortcomings and achievements, art is not suffering, but it can also - joyfully - celebrate progress (for instance, through markets, in markets); art fights with its deviant demons, and, once adequately educated, "the invisible hand" of the community could "disarm" the messengers of community division - the premise being the granting of the freedom "to change (ourselves)".

Wealth fertilizes "artistic spirits" (or at least does not poison them all the time), either because it enables them indirectly or rewards them straightforwardly. For instance, Proust did not write pop bestsellers; therefore, he might not have been able to afford the luxury du temps perdu: writing masterpieces for a niche. He could never have afforded any comfort of living with such a target audience, so it was up to his family, who believed in his genius, to entrust him with adequate resources. Another example is that of Cézanne, who lived from family allowances and inheritances. Eliot wrote poetry supporting himself from his job as a bank clerk, while Gauguin worked as a broker. Other artists have fiercely dedicated themselves to making money from art. Mozart confessed to his father in a letter that his only purpose was "to make as much money as possible... the best thing in life after health". The Strauss Family (both father and son) were also wringing every penny for every composition and concert. Chaplin recognized that he sought money from the very beginning, and art followed suit. The creation that today we label "classical" was made "with the eyes on the market": critics rejected Shakespeare as a mercantile vulgarian, while the modern novel (created by Dickens and Dostoevsky) appeared as a fine-tuning based on readers' reaction to feuilleton publishing. Paul Johnson (Art: A New History) and Tyler Cowen (In Praise of Commercial Culture) provide inspired accounts on the arts' economic life. So, selling as an artist does not mean selling oneself out as a person. 
This paper aims to reinforce the idea that value is a purely subjective phenomenon. This applies also to cultural values. The main purpose of the aforementioned reinforcement is to argue that by "democratizing" culture - or leaving it to be produced according to the consumers - it can better serve their cultural needs, but it can also sustainably support cultural producers. In other words, culture is - at least from an economic point of view - in no way different than any other need that people may display. The paper is composed of three parts, all of them dealing with the mainstream versus praxeological dialectic as regards cultural economics, emphasizing the practical consequences of the theoretical comparison.

The first part of the paper briefly discusses the concept of cultural value. As the mainstream approach of cultural economics is based on the neoclassical school's insights (especially the perfect competition model, the indifference assumption, and external costs theory), we first address the implications of this. Then we explain the inherently subjective nature of value and the role of prices as indicators - not measurements - of value.

The second part is devoted to the concept of cultural capital. After a short presentation of the meaning of capital, we expose the two main capital classification systems (stock or flow, physical and financial capital) with the purpose of critically evaluating the concept of cultural capital. We argue that cultural capital cannot be considered an innovative theoretical insight since it rests on the assumption of objective value.

The third part of the paper describes participative democracy and public administration as two fundamental institutions in the process of preserving public cultural heritage. If these two are well-functioning, cultural heritage can be accumulated and preserved. However, since these two are marred by arbitrariness, we suggest that market-based, profit-oriented, private management shall work better than public administration.

\section{"Cultural capitalism" is equally about objective calculation and market pricing as it is about ultimately subjective valuations and inestimable cultural emotions}

Studies in the field of cultural value suggest that this type of value is intrinsic to certain goods, deemed cultural. "In the case of culture, value subsists in certain properties of cultural phenomena" (Throsby, 2001, p. 19); also, "cultural value is inherent in objects or other cultural phenomena" (Throsby, 2001, p. 32). We rely on the works of Throsby, for he is one of the most influential and inspiring scholars in contemporary "economics of culture", and the pluses and minuses of his insights speak very much about the "state of the art" in the culture-interested economic profession.

\section{Mainstream "thesis" regarding cultural economic appraisal}

Regarding the economic evaluation of cultural goods, mainstream literature limits itself to uncritically invoking the neoclassical theory of price formation:

- prices formed in light of perfect available information are considered a context of equilibrium; price fluctuations cannot provide useful information on the (true) value of cultural goods; price distortions can also be caused by phenomena such as "imperfectly competitive markets" or "incomplete information" (Throsby, 2001, p. 22);

- even if acknowledging that a theory of price is not a substitute for a theory of value in economics (as prices are value indicators, not measures of value), it is argued that "price" or "willingness to pay" may not be the only evaluation criterion, since consumers of cultural goods may be ignorant or indifferent (Throsby, 2001, pp. 31);

- cultural goods not fully subject to the willingness to pay criterion can be private or public goods, falling under the "external costs theory". 
Summing up, from a mainstream/neoclassical perspective, cultural value is (i.) intrinsic, thus objective (independent of consumer valuations), (ii.) dependent to a relative extent on the economic value and consumer's willingness to pay, and (iii.) attributable to (cultural) goods that may have a public character (due to positive externalities). These characteristics pave the way for a public cultural policy, with the government assuming the role - via some sort of a "cultural technocracy" - of a tutor within the cultural market that regulates and subsidizes culture.

PICBE | 864

Praxeological "antithesis" on the evaluation of (cultural) goods

From a praxeological point of view - the Austrian School's rationally-deductive re-rooting of economic science (Mises, 1998) - value is (and cannot be otherwise than) purely subjective (Hülsmann, 2002). The praxeological preference theory of value explains that all value judgments (which are considered given) become visible only when individuals make choices or concretely demonstrate their preferences. The "quantification" (and inter-subjectivation) of such a qualitative (and subjective) reality of value materializes only in the process of economic evaluation based on monetary calculation. For this, the existence of owners of cultural goods (private property rights) and a market for exchanging them are required (Mises, 1998, p. 324).

Assuming the neoclassical economic model of prices and competition (with the assumptions that derive from the equilibrium hypothesis), Throsby arrives at the conclusion that the evaluation of cultural goods is impeded by "imperfectly competitive markets" and "incomplete information". However, this conclusion stems from an uncritically accepted assumption of the "perfect competition" model that cannot logically explain price formation (Stamate-Stefan, 2017, p. 28). Human choices and markets are always imperfectly informed and discriminatory. Even if we assume that complete information concerning a work of art can be obtained, choosing to pay for it means - in terms of opportunity costs and subjective assessments of the various schools of thought in arts - discriminating against other works" "(cultural) value".

Throsby also concludes that prices can only be a limited indicator of the economic value of cultural goods. However, as Mises $(2012$, p. 11) pointed out, "money is no yardstick of value, nor yet of price. Value is not indeed measured in money, nor is price. They merely consist of money". Thus, the economic (and cultural) value of a van Gogh work remains something attributable to people who value-judgmentally choose (informed by their cultural, ethical, moral, philosophical, religious etc. views) to sacrifice scarce resources for the purpose of possession. This is the subjective element of the process, and it is less visible for outsiders; the objective element (visible to anyone) is that a monetary price is formed, "expressing" values.

As for the "willingness to pay" for a good, as Throsby shows, it cannot be an exclusive claim criterion. While this is correct in spirit, the only exclusive claim of economics is that for cultural goods to have an "objective" expression (not measure) of their cultural value, a monetary evaluation is needed to be based on freely-formed market prices. Thus, cultural value needs owners, markets, and prices, but "cultural value" as such (i.e., for "beauty" reasons) remains hidden in the head ("eyes") of each and every person ("beholder"). These are fundamental requirements for anyone wanting to have an image of the value of cultural goods. Moreover, it can be added that no appraisal of a cultural good could unfold shortly of a price system.

A "synthesis" about about the seeing and seeding of the value of the cultural goods

From a praxeological-economic point of view, some basic conclusions can be drawn: 
- value (be it labeled economic or cultural) is subjective; nota bene - how much cultural ingredients are involved in the appraisal of an economic good is indiscernible, since valuations entail the goods in integrum, not subsets of their features;

- price is not a measure, nor an indicator of the economic value, but an objective expression of some subjective causes; nota bene - cultural value cannot be measured by prices; still, it is "signaled" via prices, not to be distorted (by controls/caps).

Some additional observations can also be made. The claim of cultural goods' public character (and thus a possible government involvement through a cultural public policy) is debatable from a praxeological and economic perspective: (i) There are no clear criteria for distinguishing between public and private goods, and even if there were, it does not follow that government "should" produce them (Hoppe, 1989; Hülsmann, 1999); (ii) The positive externalities of cultural goods still need a market to be evaluated and priced by the cultural economic agents, and it is not scientifically legitimate to conclude that their existence "requires" government intervention. It is through economic calculation and monetary prices that economic agents can eventually decide if external costs can be covered or not.

Also, there are ethical biases involved. These can symptomize the desire of culture creators to evade cultural consumers' whims. For the former, culture is a commodity whose production can be imputed to all consumers regardless of taste and cultural literacy, without the latter having to express their (vulgar) preferences regarding its structure and quality: "[Artist] hope that socialism will release them from their greatest fear: being judged by the common man" (Cantor, 2001, p. XX). However, history provides a more optimistic perspective on the "market", as the ultimate judge of cultural value: "Shakespeare wrote for the market. J.S. Bach wrote for a kind of marketplace, as did Handel. Opera and novels in the nineteenth century were spurred by a middle-class marketplace" (Cantor, 2001, p. XX).

\section{“Cultural capitalism" deals with flowing/stocked, physical/financial capital, which is entrepreneurially, rather than bureaucratically, rationalized, and structured}

What is capital? As the capital theory is mired in controversy among economic schools, there is no short answer to this essential question.

The capital theory is about capital goods; it is also about distribution theory. To complicate matters further, we can add that economists recognize capital as an institutionally conditioned economic category, reflecting historically dependent relations. At the same time, economic theory also approaches our subject matter as it was an ahistorical abstraction to discuss the perpetuity of economic activity, viz. capital as a self-generating fund.

Attempts to systematize this wide-ranging discussion have led to two broad classifications. According to the first grouping, capital can be viewed as either a stock or a flow variable (Kirzner, 1966). The second classification system distinguishes between physical capital and financial capital (Cohen, 2010; Braun et al., 2016).

In the following, without delving too much into the intricacies of these debates, we will point out that there is a realistic reconciliation of the stock flow and the physical-financial capital conundrum. Of much interest will be to evaluate Throsby's (1999) concept of cultural capital and analyze if it manages to add another dimension to the (economic) capital or if it is only a simple and a simplifying metaphor, merely to "complicate" things. 


\section{Two "capital" reconciliations in capital theory}

In matters concerning the first two categories - stock variable or flow variable -, the reconciliation is easy to make:

- capital qua present stock of higher-order goods can only come about from past saving decisions; ergo, the stock is the very result of past savings-flows that were accumulated according to a past plan;

- it is by no means a mere hodgepodge of piled up tools, but a teleologically thoroughly assembled and organized stock composed of carefully chosen and timed flows of productive resources;

- and it is, ultimately, an entrepreneurial, not simply technical, decision if the stock of capital is to be maintained (flows continue to be allocated to sustain or augment the stock) and for how long).

As for the second reconciliation - physical and financial capital -, this relies on the following insights:

- it is because the owners of the primary factors of production (nature and labor) are not willing to undergo the costs of postponing the moment when they receive their remuneration that capitalists derive their income; capitalists advance to employees and natural resource owners their payment before the proceeds from selling the end product is obtained; hence, in exchange for this service, capitalists obtain interest, and this happens at each stage of production, involving capital goods of different degrees (Hayek, 2012; Rothbard, 2009);

- businessmen invest money to acquire such resources and operate their business and evaluate production results in monetary terms; however, capital is not a universally present category of human action: any talk of capital, as a socially meaningful monetary expression, is contingent upon a particular institutional context, that is the existence of a capital market, where entrepreneurs act based on prospective monetary gains that the assets they control, as private owners, are expected to bring (Mises, 2008; Brown, 2020).

\section{"Capital" innovation in the theorizing cultural capital}

In his work, Thorsby (1999) argues that we need to add a fourth type of capital, namely, cultural capital, to what he considers to be the already consecrated triad of physical capital, human capital (Samad, 2020), and natural capital. Thorsby perceives it as a market failure, viz. the conventional economic concept of capital does not capture the influence of cultural capital on human progress and economic exchanges/transactions. He starts with an assumption - "cultural value can be measured according to a unit of account that plays a role comparable to a monetary scale in measuring economic value" (p. 6) - totally out of sync with the basics of a realistic economic theory (i.e., subjective value and the impossibility of realizing any calculation in terms of subjective use-value).

Thorsby discusses the novel idea of cultural capital: "[C]ultural capital is the stock of cultural value embodied in an asset. This stock may, in turn, give rise to a flow of goods and services over time, i.e., to commodities that themselves may have both cultural and economic value" (p. 6-7), noting that "it is likely to be a correlation between the cultural and economic value of items of cultural capital, but the relationship will be by no means a perfect one" (p. 8). Because of this imperfect reflection of cultural value in the market value of cultural capital goods, Thorsby even considers the possibility of applying investment appraisal techniques to cultural capital. This should be undertaken in the same fashion as (economic) capital is treated in financial analysis: CBA techniques might be employed for analyzing alternative projects of heritage conservation. 
"Capital" frailties in the theorization of cultural capital

As already hinted previously, Thorsby's (1999) notion of cultural capital is problematic on many accounts:

- first, there is nothing objective about cultural value. It is just a subspecies of subjective value (Copuš, Čarnogurský, 2017), which means nothing is intrinsically valuable in a good or service, while the cultural portion, although acknowledgeable, is fundamentally indiscernible, especially in quantitative, monetary (or any other kind of) commensuration units;

- second, all of Thorsby's talk of stock-flow is nothing but a dangerous metaphor with nothing but the least important things in common with the notion of (economic) capital, as it appears in economic writings, amalgamating purposefulness, usefulness, and at the same time aesthetically, craftsmanship and tradition;

- third, it has no criteria for distinguishing between a consumer's good and a producer's good. The mere stock-flow distinction comes closer to a sterile metaphor, which also applies to long term use consumers' goods, rather than identifying a new type of capital, with clear-cut treats of a production factor (i.e., capital good);

- fourth, if society values a given capital good more than what monetary calculation indicates, as Throsby laments, there are, missed by him, the profit-hungry entrepreneurs willing to buy up such undervalued item, only to later sell it in installments to the culture-thirsty. "Market failures" are not as uncurable as it is generally held.

“Cultural capitalism" adds sustainably to heritage, with the "invisible hand" created by a myriad of private hands sensibly more dexterous than state footing

Cultural patrimony/heritage, in itself, has had a rather unusual history of management or administration.

Before the rise of capitalism, (public) patrimony was often confused with the private belongings of the ruling class, as rulers or monarchs did not differentiate between what was their's (own property) and what was their state's or kingdom's (public property) (Bresser-Pereira, 1997, p. 11). A distinction between public and private only came to be made with the ascent of capitalism, which emphasized private capital accumulation.

What nowadays might be called the "management of heritage" is a result of capitalistic thought that determined private owners to accumulate wealth by investing in goods of cultural heritage. The advantage of heritage wealth is that it barely loses its value over time; on the contrary, the value even increases as time goes by. This strange quality makes cultural heritage significant both for public/governmental and private concerns (Coombe, 2013, p. 375).

Creating, preserving, and transmitting a heritage of patrimony goods to other generations seems rather difficult in public administration, as these rely on the well-functioning of two institutions: democracy and public administration (Bresser-Pereira, 1997). For accumulating and managing patrimonial wealth, both democracy and public administration need considerable improvement: the former has to become participative, while the latter needs not only to rely on mere passive administration but also the adoption of a proactive managerial framework.

- Participative democracy is key as the community (local or national) needs to get involved in preserving public heritage for future generations. Preserving public heritage is down to how well the community spirit is developed, as community members have to share the common ideal of wanting to preserve the heritage for their and their heirs' spiritual enjoyment (Guțu, 2013, p. 7). 
- Public administration of heritage is more complicated than its private counterpart, as it relies on more human interdependencies and communitarian consensus. Hone (1997) gives the example of an important - and often difficult - type of consensus that is required: the substantial, communitarian allocation of resources required to preserve the public capital, more complicated than for the private owners of cultural goods.

\section{From community spirit to tragedies of the commons}

PICBE |

868

Apart from the communitarian administration of patrimony, the public management of culture bears the virtues and (more importantly) the vices of state interventionism (Jora, Topan \& Apăvăloaei, 2018).

When it comes to public goods of culture, it is expected that the state intervenes for their preservation through law enactments or resource allocations (Benhamou, 2014). This is often the case as patrimony goods barely generate additional income; in many cases, they require resources for preservation without having the ability to produce extra money, as their primary wealth lies within the culture itself. In this case, a contradiction arises between Benhamou's idea of public interventionism and Bresser-Pereira's capitalistic management of public heritage. The more the administration of cultural property is dominated by public interventions and public resource allocations, the farther away it will drift from the mechanisms and practices of neoliberalism, which might contribute to a managerial style of identifying new sources of financing within the private sector. As in a vicious circle, the more the state is expected or used to intervene in the administration of heritage, the less that administration will benefit from the private sector's potentials (installing a sort of "crowding-out" effect).

The two main and preferred public solutions to managing cultural heritage are the aforementioned community participation and state interventionism. Chng and Narayanan (2017) advocate for more community participation because the community has a closer emotional link to and a better understanding of the local cultural heritage than a centralized government might have. The "localness" of the heritage creates a strong sense of identity that can determine the members of the community to get involved and manage or preserve what is theirs (what belongs to them). Moreover, this shared identity between the community and heritage goods generates positive feelings that can determine community members to adopt a pro-active behavior towards the heritage and increase their level of participation in the preservation. A positive externality of such involvement might also lead to a diminishing need for individual interests in favor of a rise of collective interests. However, when private and proprietary solutions are limited by public legislation, communities may easily end up trapped in "tragedies of the commons".

\section{From community spirit to private materialization}

With public administration - not necessarily interested in the present economic exploitation of the cultural goods - heritage might lose value through nothing else than non-exploitation, as it is not properly exposed to customers or consumers.

While consumerism might be severely criticized in other areas of the economy, a question arises as to whether higher consumption of cultural goods is not what actually creates acceptance for such cultural artifacts on the market and safeguards their existence through an increase in competition?

Private management of patrimonial goods is mainly dictated by the owner's wealthmaximization interests (without excluding the communitarian significances of such goods). Cultural good owners govern their cultural capital, trying to create wealth maximization options 
for themselves (Isin, 1998). In this sense, the private management of cultural goods is more prone to the logic of market competition than the public administration was. While public administration was mainly interested in preserving the cultural heritage for future generations, the private management is also interested in maximizing the utility of cultural goods at the moment of being, hence in trying to make money out of such goods for the purpose of wealth accumulation, without excluding (but, in fact, in more cases than not, more convincingly serving) the cultural benefits for future generations also.

For private management, the existence of cultural capital is nothing else than potential access to economic capital. Thereupon, one of the main differences in the management of cultural goods between public administration and private ownership is the interest that exists for the present value of the goods. While private management is more interested in maximizing the wealth of the cultural goods, as this would lead to higher monetization possibilities both in the present and in the future, public administration might be interested mostly in preserving the wealth and passing it next. Private owners have identified in cultural goods a reliable option to create private patrimony and transmit it to future generations without losing much of the par value. In private management, the par value is maintained precisely because the cultural goods are being economically exploited.

\section{Conclusion}

It is not irrevocably established that the free market destroys culture, the arts, virtue, the good, the beautiful, or the truth. It is possible that, like all instruments, capitalism is, in a sense, neutral. Freedom of expression - the quintessence of culture - is in solidarity with the free market, in which the material resources it needs for its very existence circulate (however elevated, culture needs material resources to come into being). The free market cannot discern between values, but its annulment and the violent confiscation through "cultural revolutions" of the decision regarding what "true" culture is or do not represent mistakes of epic proportions. If conceding that there is something more than a capitalist market "neutrality" vis-à-vis culture, we may easily find grounds on which capitalism powered cultures' means of expression, if not necessarily their ends too (Cowen, 2000; Johnson, 2003; McCloskey, 2006, 2010, 2016; Jora, 2016).

- Financial emancipation. While authors from previous centuries were able to support themselves only by writing pieces with truly remarkable sales, now they can earn good money through a diversity of genres and styles, across various media. Today's artists are not dependent on only one patron or client, a case in which their artistic vision was tailored to fit the caprices of such a "monopsony". Only a handful of artists could afford to play tough in front of their beneficiaries (like Michelangelo facing Pope Julius II on the subject of the artistic vision for the Sistine Chapel).

- Technical breakthrough. The extended availability of qualitative artistic material involved entrepreneurial innovations courtesy of the market. The Renaissance of Italian cities was possible due to traders that made production factors easy to obtain: color pigments, marble blocks, bronze alloys; the literary revolution in the $18^{\text {th }}$ century England was helped by the Industrial Revolution that decreased the cost of paper and increased the income of readers; modern and contemporary music grew alongside the physical solutions for recording and transmitting it. Nowadays, "classic" novels or symphonies have a daily audience greater than in the entire life of their creators; we might only think here about the abundance of digital distribution or streaming channels that enable an instant, "on the spot" consumption of classical writings or music, requiring almost no (physical) effort at all on behalf of the consumer to get 
in possession of such cultural goods: the bookstore or the concert hall have now moved, via the world wide web, within the living room of the consumer, allowing a facile, fast and - if desired by the customer - repeated consumption of cultural goods.

- Demographic changes. It also has to be considered that the world demographics have multiplied considerably since the epochs when what we nowadays term as "classic" culture was produced. The global population has increased almost sevenfold between the early $19^{\text {th }}$ century and today. Larger demographics mean more potential consumers for those "classic" cultural goods. Even if the "classic" cultural goods were produced two, three, or four centuries ago, the technical breakthroughs described earlier, combined with the demographical boom experienced since the creation of those goods, have multiplied the consumption and (re-)consumption possibilities of such "classics". By mere quantitative standards, there are seven times more people across the globe today than there were a couple of centuries ago. These people are potential consumers of cultural "classics".

- Democratized creations. Despite lamentations that minorities or disadvantaged groups (AfricanAmericans, Jews, women etc.) risk being underrepresented in free artistic markets, history tells us the opposite. African-American blues music, discriminated by mainstream radios, was spread through jukeboxes, a decentralized medium for their music, beyond its Louisiana birthplace. Jewish immigrants - proverbially endowed with financial capital and trade spirit - built Hollywood's film empires, smoothly immersing in the American pop culture. Women-writers conquered broad audiences. Moreover, the big corporations" "for-profit-multiculturalism" pays more than the "politically correct" one.

One more brief remark. The ritually lamented separation between "high" culture (creations that receive the highest praise from critics) and "low" culture (the most popular creations) rather reflects the diversity and sophistication of today's culture and not its corruption. Today's artists are entrepreneurial - like it or not. They target large or small audiences and take more or fewer risks. Without falling into the trap of "artistic ecumenism" - "variety is good, period" -, it is essential to understand that capitalist order is valuable as a premise. State intervention can hinder culture. "Gresham's law": politically overrated kitsch drives the aesthetic good out of the market.

\section{References}

Austrian Economics Newsletter (2001). Austrian Economics and Culture. An Interview with Paul Cantor, Ludwig von Mises Institute, Auburn, Alabama.

Benhamou, F. (2014). Neoliberalism and French Heritage Policy in the Context of Globalization, Heritage \& Society, 7(1), 47-56.

Braun, E., Lewin, P., \& Cachanosky, N. (2016). Ludwig von Mises's Approach to Capital as a Bridge between Austrian and Institutional Economics, Journal of Institutional Economics, 12(4), 847-866.

Braun, E. (2020). Carl Menger: Contribution to the Theory of Capital, Section V (1888), Journal of Institutional Economics, 16(4), 557-568.

Bresser-Pereira, L.C. (1997). Managerial Public Administration: Strategy and Structure for a New State, Journal of Post Keynesian Economics, 20(1), 7-23.

Chng, K.S., Narayanan, S. (2017). Culture and Social Identity in Preserving Cultural Heritage: An Experimental Study, International Journal of Social Economics, 44(8), 1078-1091. 
Cohen, A.J. (2010). Capital Controversy from Böhm-Bawerk to Bliss, Badly Posed or Very Deep Questions? Or What "We" Can Learn from Capital Controversy Even If You Don't Care Who Won, History of Economic Thought, 32(1), 1-21.

Coombe, R.J. (2013). Managing Cultural Heritage as Neoliberal Governmentality. In: Bendix, R. F., Eggert, A., \& Peselmann, A. (Eds.): Heritage Regimes and the State, 375-388, Göttingen Studies in Cultural Property (Volume 6), Göttingen: Universitätsverlag Göttingen.

Copuš, L., \& Čarnogurský, K. (2017). Intercultural marketing: Culture and its influence on the efficiency of Facebook marketing communication, Management \& Marketing. Challenges for the Knowledge Society, 12(2), 189-207.

Cowen, T. (2000). In Praise of Commercial Culture. Cambridge, MA, Harvard University Press.

Guțu, G. (2013). The Particularities of Administration Public Property of Local Collectivities, Contemporary Legal Institutions, 5(1), 1-7.

Hayek, F. (2012). Prices and Production \& Other Works, Auburn, Alabama, Ludwig von Mises Institute.

Hone, P. (1997). The Financial Value of Cultural, Heritage and Scientific Collections: A Public Management Necessity, Australian Accounting Review, 7(13), 38-43.

Hoppe, H.H. (1989). A Theory of Socialism and Capitalism, Boston, Kluwer Academic Publishers.

Hülsmann, J.G. (1999). Economics Science and Neoclassicism, The Quarterly Journal of Austrian Economics, 2(4), 3-20.

Hülsmann, J.G. (2002). From Value Theory to Praxeology (Introduction to the third edition of Mises, L.v. Epistemological Problems of Economics), Ludwig von Mises Institute, Auburn, Alabama.

Isin, I.F. (1998). Governing Toronto without Government: Liberalism and Neoliberalism, Studies in Political Economy, 56(1), 169-192.

Johnson, P. (2003). Art: A New History, New York, NY, Harper.

Jora, O.D., Topan, M.V., and Apăvăloaei, M.A. (2018). Sisteme economice comparate. In Hurduzeu, G. and Nicolescu, L., Relații economice internaționale: teorii, strategii, politici, instrumente și studii de caz. București, Editura ASE.

Jora, O.D. (2016). Spiritualitate, materialitate și proprietate. Cultura mea, cultura ta, cultura noastră, cultura lor, București, Editura ASE.

Kirzner, I.M. (1966). An Essay on Capital, New York, Augustus M. Kelly.

McCloskey, D.N. (2006). The Bourgeois Virtues: Ethics for an Age of Commerce, Chicago, University of Chicago Press.

McCloskey, D.N. (2010). Bourgeois Dignity: Why Economics Can't Explain the Modern World, Chicago, University of Chicago Press.

McCloskey, D.N. (2016). Bourgeois Equality: How Ideas, Not Capital or Institutions, Enriched the World, Chicago, University of Chicago Press.

Mises, L.v. (1998). Human Action. A Treatise on Economics, Ludwig von Mises Institute, Auburn, Alabama.

Mises, L.v. (2008). Human Action: A Treatise on Economics. Auburn, Alabama: Ludwig von Mises Institute.

Mises, L.v. (2012). Economic Calculation in the Socialist Commonwealth, Ludwig von Mises Institute, Auburn, Alabama.

Rothbard, M.N. (2009). Man, Economy, and State, with Power and Market, Auburn, Alabama, Ludwig von Mises Institute. 
Samad, S. (2020). Achieving innovative firm performance through human capital and the effect of social capital, Management \& Marketing, Challenges for the Knowledge Society, 15(2), 326-344.

Stamate-Ștefan, A. (2017). Real și imaginar în teoria economică a concurenței. O interpretare în tradiția Şcolii Austriece de economie, București, Editura ASE.

Throsby, D. (1999). Cultural Capital, Journal of Cultural Economics, 23, 3-12.

Throsby, D. (2001). Economics and Culture, Cambridge University Press. 